\title{
Researching the morphology of the city's internal micro structure: UPM Urban Parterre Modelling
}

\author{
Angelika Psenner, Klaus Kodydek \\ Department of Urban Design. Vienna University of Technology. Vienna, Austria \\ E-mail: angelika.psenner@tuwien.ac.at, klaus.kodydek@tuwien.ac.at
}

\begin{abstract}
As conventional cadastral maps only show building perimeters, they contain no information about the city's internal structure-about the complex interplay of architecture and its socio-economical use. Thus urban planning seems to spare little thought for what really takes place inside the buildings lining a street, although we perfectly know that the potentials of ground floor use and the structure of the correlating public street space are directly related. The Urban Parterre Modelling UPM-method refers to the city's "parterre" as a holistic urban system: it covers both built-up and non-built-up areas. Thus street, ground floor and courtyard are treated as entity, so that their interrelations can come to light. Technically the method represents the merging of a common $3 D$-city-model and a Comprehensive Ground Plan Survey CGPS - a researching technique used in the 1960s until the late 1990s (throughout Europe, but mostly in Italy, France and Switzerland).
\end{abstract}

Keywords: StadtParterre (urban parterre); Ground Floor Use; Urban Space Research; Vienna

\section{Introduction}

A clearly new urban research method has been developed and tested in a pilot study by means of an in depth exploration of a typical historical street in Vienna (the streets' length is 190 meters). In September 2015 a new four years' research program was financed by the Austrian Science Fund (Austria's central funding organization for basic research, FWF) and launched at the Department of Urban Design at Vienna University of Technology; under the lead of Angelika Psenner. Within this operational framework the Vienna urban parterre is being investigated in terms of an exemplary neighbourhood in the 9th district, an archetypal GZ area totally rebuilt in the late 19th century. It covers three adjacent roads (A, $\mathrm{B}$ and $\mathrm{C})^{1}$ and altogether expands a length of almost one kilometre. Preliminary research was informed by an in-depth theoretical and historical approach, covering the following subjects: impact of relevant legislation ${ }^{2}$; urban planning and architecture (elaborate study on the unique architectural type of the 'Viennese GZ townhouse; cf. Psenner 2012a).

In order to better read the streets' position within the larger urban fabric, the biography of the street was extensively researched, including detailed information on layout (topography and urban planning), architectural development (historical and current building plans on the selected lots) and over time use structure development of ground floor and basement premises. Trading documents, business licenses and tax regulations are evaluated in order to enable the modelling as well as the drafting of house-biographies for each single building in the chosen field.

Given the methodological perspective the paper is addressing the following issues:

-How is the UPM, un utterly precise 3D-model of an exemplary sample of the Viennese StadtParterre (urban parterre), made and in 

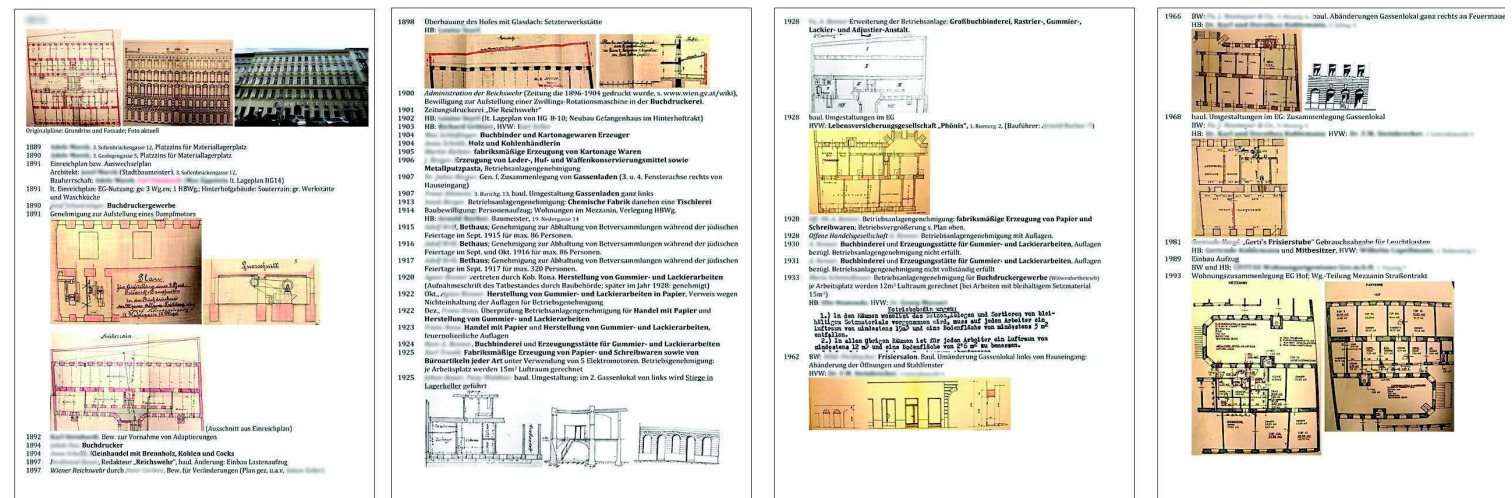

Figure 1.

Exemplary house biography, one out of 70. Source: ㄷ Psenner

what does it differ from standard city models? -What are the key challenges in managing and processing the necessary big data?

\section{The Two-Dimensional Comprehensive Ground Plan Survey (CGPS)}

Originally, the two-dimensional Comprehensive Ground Plan Survey (CGPS) derives from studies on the relationship between urban morphology and building typology, like the ones by Saverio Muratori in Venice and by Gianfranco Caniggia in Florence and Como (cf. Muratori, 1960 and Caniggia, 1963).

Several such morphological studies were subsequently conducted by Swiss architects and historians: in the 1960s, architects in the canton of Tessin initiated an inventory that was continued at the Swiss Federal Institute of Technology (ETH) in Zurich in the 1970s; ${ }^{3}$ further progress in the field was made with a comprehensive survey of Zurich's urban centre under the direction of architectural researcher Margareta Peters (cf.: Peters, 1990 and 1999).

Conventional cadastral maps (called Flächen-Mehrzweckkarten MZK in Vienna) provide no sufficient information about ground floor plans and the structure of urban interiors, whereas a Comprehensive Ground Plan Survey (CGPS) sets buildings in relation to public space and their topographic environment, by thus visualizing the interrelation between the interior life of individual buildings and the public street space surrounding them and therefore accurately useful to examine the relationship between buildings, streets, and courtyards. Beside the ground floor CGPSs often cover the basement and a standard upper floor, some also include a typological register, specifying the particular building type (Muratori, 1960; Caniggia, 1963; Malfroy, 1986).

\section{New approach: Three-Dimensional Urban Parterre Model (3D-UPM)}

A baseline set of data is provided by the existing digital cadastral map MZK, which documents detailed land use for the entire municipal area of Vienna. It is a fundamental tool, a matrix that is filled in with ground level plans of individual buildings - covering both historical floor plans and documented building uses as well as most recent conversion records ${ }^{4}$, so as to reflect the morphological evolution of the StadtParterre. All plans are then verified on site and, if necessary, adapted and amended, in particular with regard to actual building uses.

Given the importance of ceiling and building heights ${ }^{5}$, one of the study's primary objectives is to provide a three-dimensional model of the urban parterre. To do so, the method was developed further into what is called 3D-UPM (Three-Dimensional Urban Parterre Model). This 3D representation of the data-the modelling is done with Autodesk Revit ${ }^{\circledR}{ }^{6}$ now enables profound analysis of the links between buildings' interior and exterior spaces. Subject to the UPM the following matters are discussed: Where is, or was, the basement or courtyard directly connected to ground floor use? How do these interior connections affect 

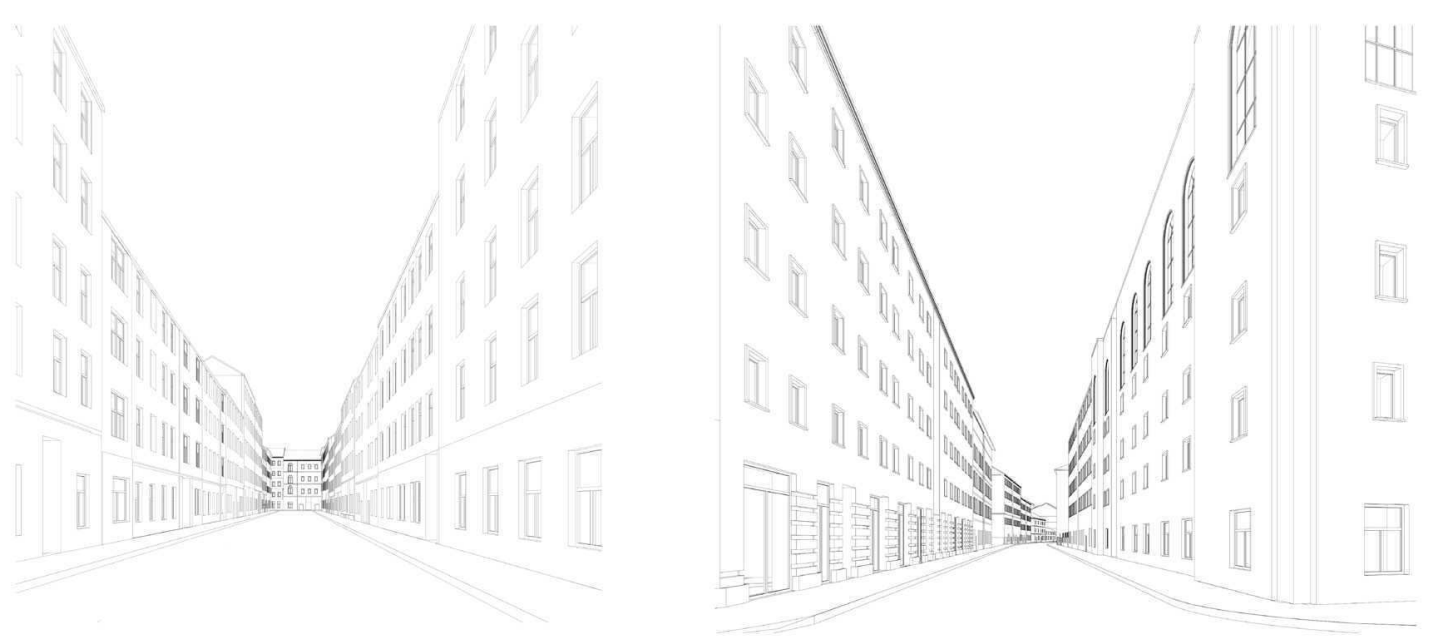

Figure 2.

3D-UPM: investigating the city at eye level. Source: $(\mathcal{C}$ Kodydek/Psenner

the entire parterre function? The introduction of $3 \mathrm{D}$ and the space usage interpretation are the major differences to the former CGPSmethod $^{7}$.

The UPM depicts the ground floor is rendered in every detail, while for the standard upper floor and basement a set of simple structural data, such as weight bearing elements (main supporting walls), access points (stairways and corridors) and the façade-structure (opening axes), provides sufficient information. Where the adjoining levels (basement and first upper floor) are directly connected with the ground floor by stairs, doorways or (freight) elevators, they are treated as extensions of the ground floor and therefore represented in detail. Thus the UPM, a particularly sound representation that also includes basic information on ground floor "furnishing" (i.e. colour codes for differentiated use structure and cars/ double parkers) is used to examine the internal relations of the StadtParterre. As it produces precisely the information needed for defining the building's relationship to public space. With rendering the alley's geometric profile (street width and building size) the daylighting conditions on the ground floor and street level are expressively depicted.

The (historic) facade is interpreted as a permeable interface between building and public space, with information on the formal façade design being available as an option. In this sense the UPM represents a special type of
3D urban model, with precise detail data and a ground-level perspective. As known, standard 3D urban models mostly provide a bird's eye view and do not contain the information needed for a ground-level investigation.

\section{Carrying out of the UPM}

Due to its high level of detail the UPM fundamentally differentiates from current city models created with City-GML. The LoD Charta was used as point of reference in the modelling process. Yet, the Charta may not be applied fully as the current classification does not offer an adequate category: $\mathrm{LoD}^{8}{ }^{8}$ which would be the nearest - differs insofar that in UPM the façade is being handled in its urban structural not in its textural significance. Keeping in consideration that the authors' interest lies within the urban design perspective, little importance was attached to an accurate modelling of façade-textures ${ }^{9}$. After a significant revision of the UPM-method in March 2017 the LoD4 standard is now being applied on every single floor level - initially it was used on ground floor and basement level only.

The realization of the UPM is carried out in five major steps: approach to data and data gathering; data processing; first analysis (preparing and formatting of data; modelling and visualization. 


\begin{tabular}{|l|l|l|}
\hline STAGE & TASK & EQUIPMENT \\
\hline $\begin{array}{l}\text { Approach to data } \\
\text { and data gathering }\end{array}$ & $\begin{array}{l}\text { In depth archive research at Vienna Building Authority MA37; } \\
\text { extensive on-site field trips }\end{array}$ & $\begin{array}{l}\text { Digital Camera } \\
\text { (Sony Alpha. 6000+) }\end{array}$ \\
\hline Data processing & Organize data & Microsoft Word, Microsoft Excel \\
\hline $\begin{array}{l}\text { First analysis; } \\
\text { preparing and } \\
\text { formatting of data }\end{array}$ & Information extraction; house biographies & Microsoft Word, Microsoft Excel \\
\hline Modelling & 3D-UPM & Autodesk Revit \\
\hline Visualization & Analysis of the studied object; Comprehensive ground floor study & $\begin{array}{l}\text { Autodesk Revit, Adobe } \\
\text { Illustrator, Adobe Photoshop }\end{array}$ \\
\hline
\end{tabular}

Table 1.

Stages of methodology

The key for the modelling process is precise and detailed information about every single building and their relation to public space. Data is gathered in different archives: Vienna building authority (which holds most of the documents and plans, as well as many handwritten manuscripts), Vienna Museum, District Museum, Austrian National Library (ONB) and Wiener Stadt- und Landesarchiv. Repeated extensive on-site field trips veritably add to the approach.

The building authority archives hold rich information on every single lot in the city; each one has its own dossier, containing detailed documentation on the building process: application plans, construction permits and documented uses of most of the ground floor premises. Therefore, the building authority archives play a vital role in the approach to data. In an in-depth archive research, every single document is being photographed and thus digitalized. The dossier volumes vary in size depending on the building activity over the years and on whether constructions were applied for and recorded.

The historical maps - some of those in real poor condition (see fig.1) - carry a wide range of information such as site plans, sections, floor plans and relevant details. In order to get accurate reproductions, serial pictures of the historic maps are taken, ranging from an overview picture of the whole map to a zoomed in picture of the specific plans. Being the solid base of information for the modelling process, the taken images must not be distorted or blurred; so that key information such as heightlevel measurements, dimensions of various building parts, annotations and any kind of handwriting are perfectly visible and readable. (Photocopying is not feasible in this stage of data-gathering, because of the bad condition of most plans and because of the large dataamount (big data).

Repeated on-site field trip investigations are necessary in order to verify ambiguity and uncertainties arising on the fact most of the
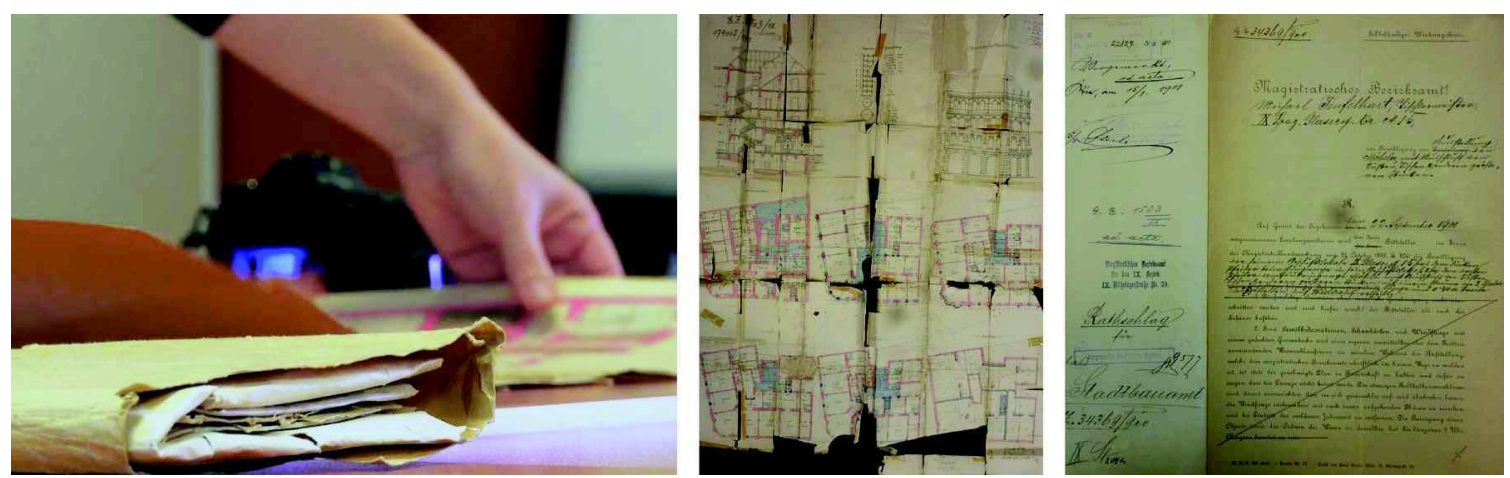

Figure 3.

Historic documents that are archived in Vienna Building Authority Department. Source: left: film-still from video by Karina Hurnaus about the researcher Psenner and the ongoing research project: https://www.youtube.com/ watch?v=vUJSA2N-zbA; others: () Psenner 
time the archive dossiers do not dispose the (now common) inventory plans ${ }^{10}$. Therefore, mismatches between historic plans and actual as-built constructions are to be found rather frequent ${ }^{11}$.

The actual nowadays buildings are being photographed as well; which proves to be rather helpful for additional information and control. And in order to study the buildings on an urban design level (i.e. permeability of the façade structure) the single house-pictures are merged to form a continuous strip of streetfaçade-panoramas.

All collected data (archive and on-site) is then unified and organised in an accurate way. This big-data management proves to be rather laborious: firstly, the information is divided by street, every single lot has its own folder, containing the building authority archives information as well as the on-site material. Then this data is being evaluated and prepared for the modelling process.

For creating the UPM the following data is being used:

-the cadastral map (MZK)

-historical plans (building authority and other archives)

-on-site photographs

$-3 \mathrm{D}$ libraries (used as the basic elements for the model).

The 3D modelling is set on reference to the official cadastral map MZK, which contains
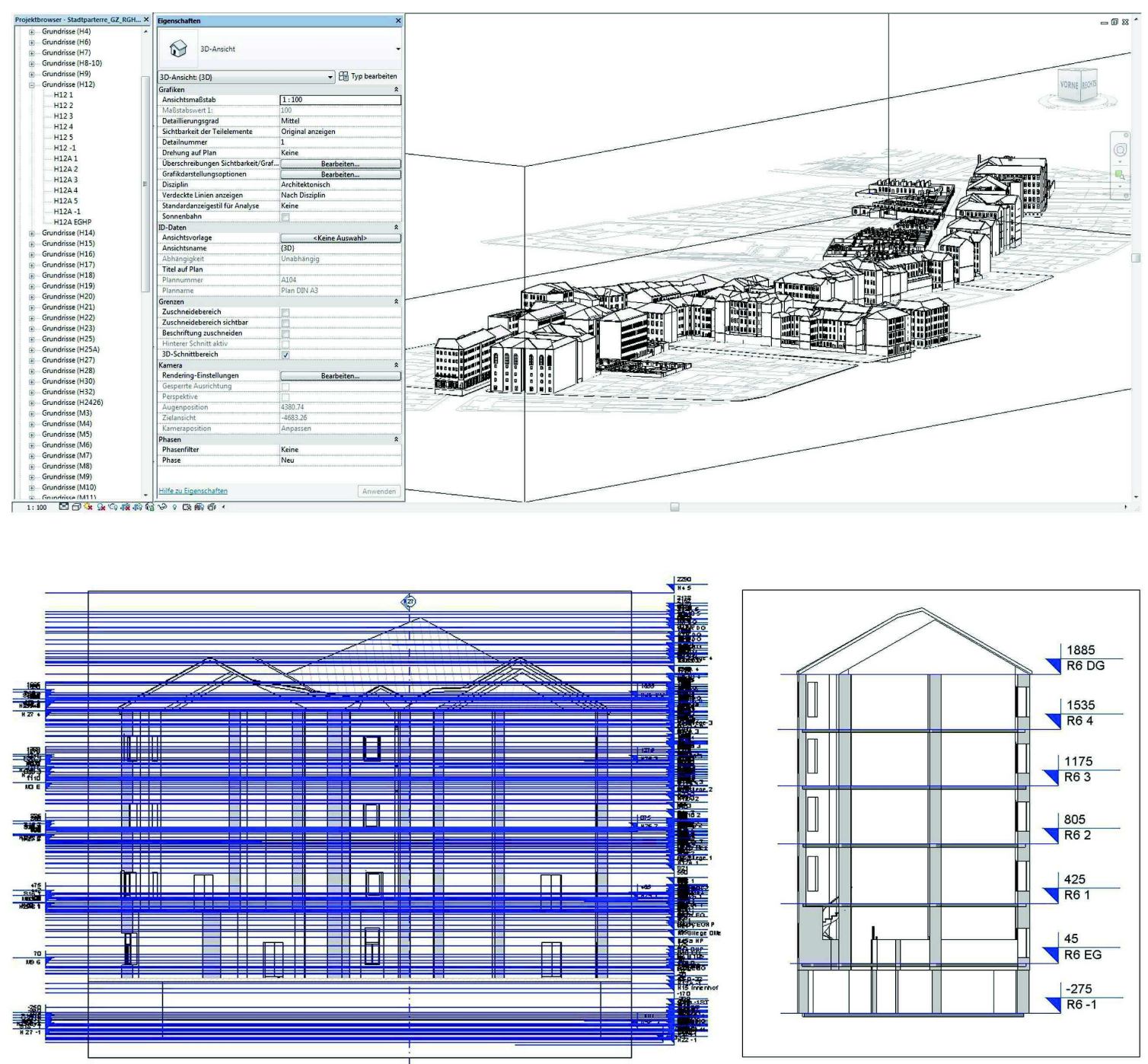

Figure 4.

UPM modelled in Autodesk Revit ${ }^{\circledR}$; data management: left image showing all levels concerning the model; right: big data is being arranged in a readable way: extra floor plan view for each building containing nothing but the relevant floor plans. (C) Kodydek / Psenner 
all base-line information; such as street width, outlines of the houses. In consequence this macro-information is being combined with data concerning the micro-structure on edificelevel. The model's high level of detail standard is being ensured by thoroughly incorporating differentiated information derived from the historical building plans:

a. exact building height

b. differing room heights (the historic Viennese townhouse shows varying storey heights: normally the ground floor is the highest, from bottom to top the storey height decreases remarkably; cf. Psenner 2012 and 2014a)

c. roof type, shape of historical roof formations and more resent rooftop conversions

d. level of the ground floor in reference to the topographical level (cf. Psenner 2017b)

e. façade: basic structural elements such as windows, doors and essential tectonic details

f. inner connections to adjacent floors (cellar, basement and upper level): stairs, trap doors, (freight) elevators

g. outer connections to open space: accessibility courtyards; alley doors.

\section{Analysis - dealing with big data}

The exemplary StadtParterre being investigated is in the 9th district, an archetypal GZ area totally rebuilt in the late 19th century. The UPM covers three adjacent roads (A, B and C) and altogether expands a length of almost one kilometre. The street stretch formed by A and $B$ is 810 meters long; it counts 56 houses. Street $\mathrm{C}$ - which is an orthogonal side street to the previous - measures 144 meters with an additional 14 houses $^{12}$. This adds up to a total model length of 952 meters and a total of 70 buildings.

The modelling is done with Autodesk Revit $\AA$, a programme chosen for its coordinated and consistent model-based approach. It allows integrating $\mathrm{CAD}$ data, such as the digital cadastral map MZK. The 3D elementscalled Families - were selected from Revit ${ }^{\circledR}$ libraries and other open source databases such as Revitcity. Some site-specific elements, such as certain wall constructions, were created in Revit without using a the 'family' option.

In a first approach the research field was divided into five blocks of similar size-as it could not be estimated whether the whole street length (big data) was manageable in one

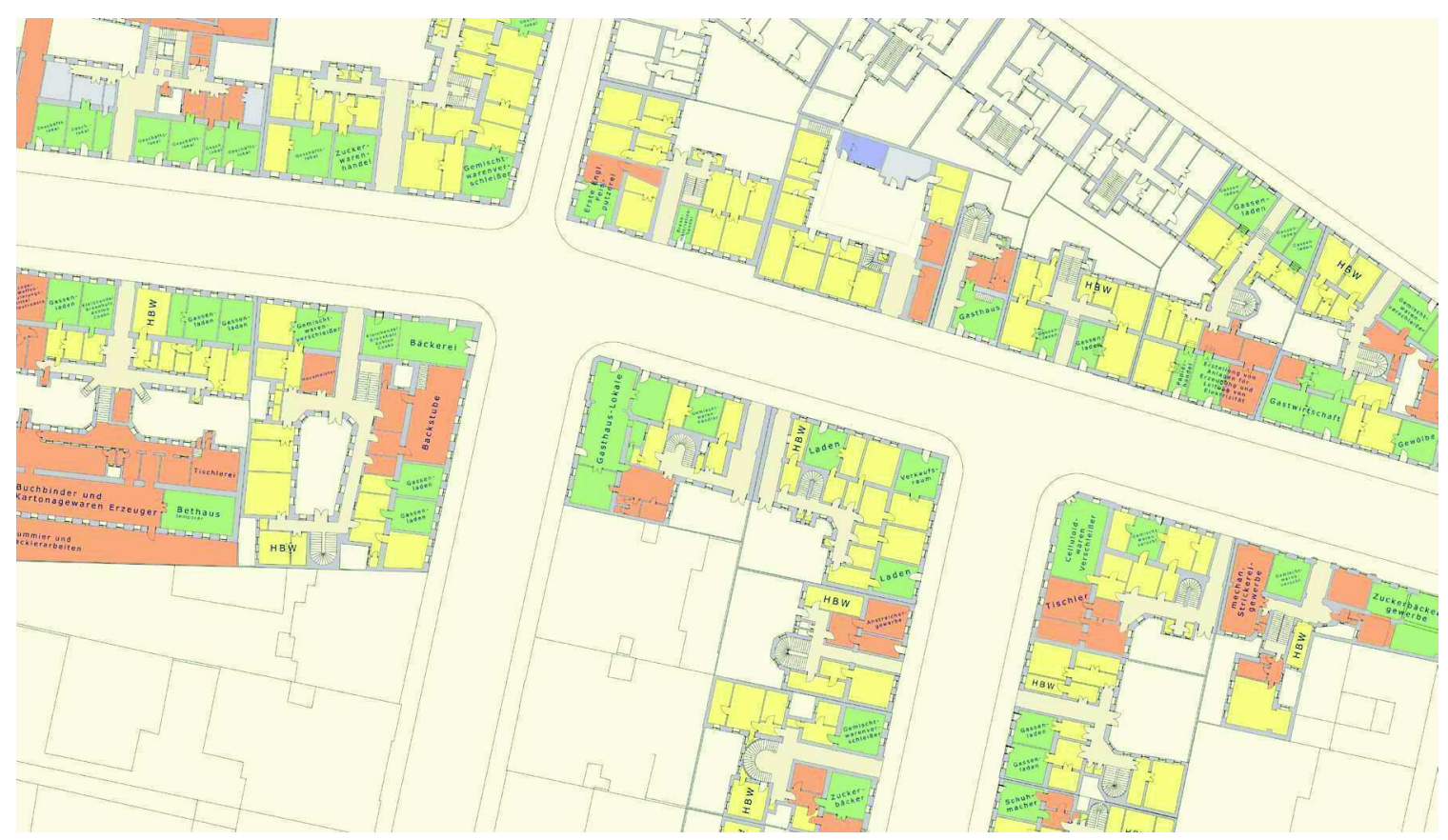

Figure 5.

UPM showing the research field - use structure analysis for historic status (around 1910). (C) Psenner 

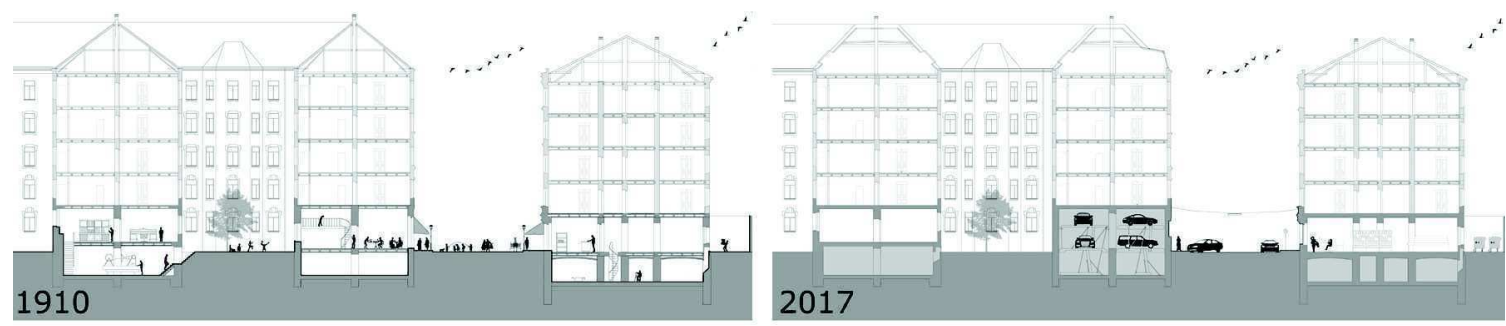

Figure 6.

Section views of the StadtParterre of the 1910-status and the current status; while the historic StadtParterre functioned as a uniform, inter-connected structure, the exchange between the various zones is no longer given today. (C) Kodydek / Psenner

single model. But during the initial work phase, the data load turned out to be developable so that one big model was created on one single dataset. This means that data managing is becoming a number one feature: The different floor plans of one building are grouped into one floor plan view named after the house number; thus a total set of 70 different floor plan views are created.

With the 'plan regions' tool and by defining cut planes at different heights the programme allows to envision specific areas in order to produce the visualization needed (e.g. for Souterrain and spilt levels, which are quite present in the research area). This facilitates a precise analysis of the interconnection of different StadtParterre spheres over time: ground floor and adjacent rooms in basement or first floor. As two different UPM-phases are being produced-one depicting the status of around 1910 and one showing the current situation - the seminal time factor is taken in.

The information of the afore mentioned house biographies is being processed by including the various uses categorizations of all single ground floor premises via a special colour code schema: green stands for semipublic use (with high use frequency and direct connection to the public street space); orange stands for production, yellow for living, grey for storage and blue for garages. The Revit ${ }^{\circledR}$ tool "Rooms" is uses to marked this reference within the building model base on room-bounding elements. Thus the model offers highly detailed, multi-dimensional information.

The model allows to create section views through every single building, thus revealing precise insight on varying storey heights, on structural information, and on the vertical and horizontal interconnectedness of the StadtParterre, which as we know has to be seen as a holistic urban system.

\section{Outlook}

In the pilot study (2012-2014) the modelling had to be outsourced due to budget reasons; whereas in the ongoing research project, an inhouse 3D modelling position is provided. Thus the process was adjusted and fitted for the actual research goal. Currently the methodology is again undergoing an evaluation process: by identifying weaknesses - mostly mentioned in the text above - it shall be improved further.

The systematic 3D modelling of the historic structure and the current situation was undertaken simultaneously, which turned out to be rather time consuming; hence the modelling of the historic status shall be performed and finished before applying the changes and adapting it—by using the "phase" tool.

\section{Conclusion}

The complex micro-analytical possibilities of the Urban Parterre Model UPM allows to document vacancies and other issues relating to street-use in selected neighbourhoods and to analyse the contributing economic, traffic and social factors. Systematic 3D modelling of the built-up environment and taking inventory of historical, current, and potential groundfloor uses thus will provide a basis to put Vienna's street-level environment in a longterm development perspective as a practical 
guideline for future interventions in various neighbourhoods and for the (re-)designing of individual street complexes ${ }^{13}$.

From an international research perspective, another innovative asset of the project is the three-dimensionality of the comprehensive model. Successful regulatory measures in urban planning, administration, and economic policies depend on sound and detailed knowledge of the actual architectural structure as well as the current actual-and potentialuse of the street-level environment. Urban Parterre Model provides this information in easily accessible and locally contextualized form. Thus, the development potential of the street-level environment can be clearly identified to inform urban planning.

UPM is a ground-breaking method that can provide data that are highly utilizable for urban research (and planning), including in particular computer-based simulations. The UPM including the historical analysis of the overtime transforming relationship between the built-up and the non-built-up urban street level environment in will be a sound basis for further in-depth analysis. The benefits that may be expected from this approach include that

-the UPM method visualizes the (historical) interrelation between street space and ground floor use over time and identifies existing discrepancies between private use of the street space and the public interest in having other (and yet unavailable) offerings of the streetlevel environment;

-reliable planning and implementation of concrete improvement of the urban street-level environment will be possible.

In any case, the application possibilities go far beyond the situation delineated in this present study, as the UPM will be usable not only in an urban context, but also in suburban or rural settings, for example, to study and address in regional planning terms certain architecture-related aspects and conditions of the problem of vacancies in rural areas (small towns, rural communes, and villages). Once fully developed, the analytical UPM approach may also be applied to any other critical StadtParterre situation in urban peripheries or shrinking city situations.

\section{Notes}

1 For data protection reasons - since plan data for individual buildings in Austria is considered to be private - detailed information about the Viennese StadtParterre (urban parterre) in question are anonymized, when disseminated.

2 Building regulations, commercial code, public health care and road traffic regulations, tax incentives, urban planning, etc. (cf. Psenner 2012, 2014a, 2014b, 2017b).

3 CGPSs are available for most Swiss towns and cities; manly covering the historical city centres; amongst others: Bellinzona, Lucerne, Bern, Solothurn, Biel, Zurzach, Lelandron, Baden, Wil SG, Zurich (old town and industry quarter).

4 Plans are kept on file in the database of the Vienna Municipal Building Authority Department. Unlike in other countries (e.g. Italy and Switzerland), detailed plan data for individual buildings, which contain precisely the information needed here, are considered private under data protection laws in Austria. Which is why all research and findings have to be anonymised in the present paper.

5 Building height is the factor that determines the extent and type of shading of the street space and lower floors. In relation to street width, GZ buildings are rather tall, which leads to disadvantageous daylighting conditions particularly on the ground floor. The typical Viennese multiple-storey apartment building has exceptional ceiling heights (3.20 to $4,95 \mathrm{~m}$ ), which allows for specific and highly flexible types of use. (Psenner 2012, 2014a)

6 Revit ${ }^{\circledR}$ is a standalone application that includes architectural design, MEP and structural engineering, and construction features. The program was developed as a specific Building Information Modelling (BIM) tool which facilitates a coordinated and consistent model-based approach. It supports easily controllable transparency and fadein/-out effects based on flexible keys for all objects. Cf. Clayton 2014.

7 The Ponticelli / Naples ZGA includes axonometric plans, which, however, only show building skins (Fioravanti quoted in: Caniggia 1986, p. 336). 
8 LoD4: The building's geometrically detailed outer shell and interior is represented by detailed surfaces and roof shapes. All kind of surfaces and additional movable and nonmovable building elements (e.g. balconies, chimneys, stucco, ledges, etc.) may be represented with greater detail as semantic objects.

9 If it proves to be decisive to have precisely visualised façades, the current model can be easily adapted to this.

10 Nearly always (minor) differences between a historic application plan and the as-built construction are detected; as many decisions are to be taken on-site, when problems arise while construction is going on. Nowadays building authorities generally ask for an official "notification of competition", which must include a so-called "Bestandsplan" (inventory plan).

11 Due to the large number of buildings being surveyed, the impossibility to enter those private houses and the given time and financial resources, follow up measurements in every single building is beyond question. For that reason, the MZK, the existing plan documentation and the on-site verifications are used to iteratively approximate the precise form.

$12 \mathrm{C}$ shows a high ground floor retrofitting into garages and was chosen for exactly this reason.

13 In order to develop a sustainable solution to the various problems that afflict the Vienna street-level environment, it will be necessary to employ a systemic view of urban structures. One objective of this study is an in-depth analysis and representation of these interrelations.

\section{References}

Caniggia, G. (1963): Lettura di una cittá: Como. Rome: Centro Studi di Storia Urbanistica.

Caniggia, G. (1986): "Lettura di Firenze Strukturanalyse der Stadt Florenz". In Malfroy/ Caniggia: Die morphologische Betrachtungsweise von Stadt und Territorium. Zürich: ETH, Lehrstuhl $\mathrm{f}$. Städtebaugesch.
Fortier, B. (1989): La Métropole Imaginaire: Un atlas de Paris. Brussels: Peirre Mardaga.

Gil, A., (2016): "Virtual reconstruction of monastic Lisbon: case studies". In: 13th International Conference on Urban History, European Association for Urban History. Finland, 2016. Available for download at: https://www.researchgate. net/publication/308166287 From the city scale to the building scale Virtual reconstruction of monastic Lisbon (08.04.2016)

Malfroy, S. and Caniggia, G. (1986): „Die morphologische Betrachtungsweise von Stadt und Territorium“. Zürich : ETH, Lehrstuhl f. Städtebaugeschichte

Muratori, S. (1960): Studi per un operante storia urbana di Venezia. Roma: Istituto Poligrafico e Zecca dello Stato, Liberaria dello Stato.

Murteira, H. (2013): Myth and Reason: Lisbon's image before and after the 1755 earthquake. Review paper presented at The Image of the City transformed: 15th18th Century. Antwerp: Faculty of Design Sciences, University of Antwerp, Artesis University College.

Peters, M. (1990): „Stadtgrundriss als Arbeitsinstrument: dem Mittelalter auf der Spur“. In: Hochparterre 1990/4, 30-31 (http://dx.doi.org/10.5169/seals-119191) accessed 23.10.2017

Peters, M. (1999b): „Elektronische Erfassung eines Industriequartiers: zusammenhängende Grundrissaufnahme in Zürich, ein Experiment". In: Schweizer Ingenieur und Architekt, Vol.117, 779-784.

Psenner, A. (2011): „Integrative Diversität zu ebener Erd'? Das Entwicklungspotenzial der stadträumlichen Struktur des Wiener Gründerzeit-Parterres", in: Sozialwissenschaftliche Studiengesellschaft (ed.), SWS Rundschau, Heft 2/2011, 195218

- (2012): „Mixed Building Use Promotes Mixed Urbanity: Insights from Historical Use-neutral Architecture", in: M. Schenk, V.V. Popovich, P. Zeile, P. Elisei (eds.) REAL CORP 2012, RE-MIXING THE CITY Toward Sustainability and Resilience? Wien, 2012, 463-473. Available for download at: http://www.corp.at/archive/CORP2012_18. 
pdf; (15.05.2017)

- (2014a): Das Wiener Gründerzeit-Parterre: Eine analytische Bestandsaufnahme. Pilotstudie (Abschlussbericht der Studie). Vienna: TU Vienna, Dept. for Urban Design. Available for download at: http://publik. tuwien.ac.at/files/PubDat_240533.pdf; (15.05.2017)

- (2014b): „Don’t Even Think Of Parking Here. Wiener Straßenraum: Verhandlung von Nutzungsrechten und Nutzungsansprüchen“, in: Ingo H. Warnke und Beatrix Busse (eds.), Place-Making in urbanen Diskursen - Interdisziplinäre Beiträge zur Stadtforschung,, Boston/Berlin: de Gruyter, 121-147

- (2015): „Fakten zum Wiener GründerzeitParterre und seinen Nutzungschancen" in: E. Raith, FB Städtebau, TU Wien (ed.): Mission Mikrourbanismus. Kurze Nacht der Stadterneuerung IV, Vienna, 110-118

- (2017a): „Funktionen des „Ebenerds“ StadtParterre reloaded" in: Österreichische Gesellschaft für Architektur ÖGFA (ed): Umbau, Vienna: Birkhäuser / De Gruyter

- (2017b): ,'Wiener Null' - Levelling the City of Vienna" in: EURA Conference 2017; Cities locked in networks, Warszawa Poland

- (2017c, forthcoming): Spatial Representation of Vienna's Street-Level Environment-Urban Parterre Mapping (UPM). In: Murteira, H. / Forte, M.: Digital Cities in-between History and Archaeology. Oxford University Press.

Ruegg, A. (ed.) (1975): Materialien zur Studie Bern. 4. Jahreskurs 1974/75. Zurich: ETH/ Schnebli/Hofer

Whyte, W.H. (2016 orig.: 1980): The Social Logic of Small Urban Spaces. NYC: Project for Public Spaces.

Wüstenrot Stiftung (ed.) (2014): Herausforderung Erdgeschoss - Ground floor interface. Berlin: Jovis. 